\title{
Who Acts for the EU before and after the Lisbon Treaty? The View through the Media in Singapore and Thailand
}

\author{
Yeo Lay Hwee \\ Loke Hoe Yeong \\ European Union Centre in Singapore \\ 11 Slim Barracks Rise, 06-01 \\ Executive Centre \\ 138664, Singapore \\ E-mail: eucylh@nus.edu.sg \\ E-mail: eucv18@nus.edu.sg
}

\begin{abstract}
This paper seeks to determine whether the EU has accomplished its objectives concerning the visibility of EU external action, which the Lisbon Treaty sought to achieve. The role of Catherine Ashton as the EU's High Representative of the Union for Foreign Affairs and Security Policy, together with the newly formed European External Action Service (EEAS) which supports her work, aimed to "effectively project European values and interests worldwide" (Šefčovič, n.d.) and to make Europe "an actor on the global stage" (Europa, n.d.). Despite the sui generis nature of the internal functioning of the EU, there is a strong case in academic literature that the EU can be studied as an international actor like any other state actor. Southeast Asia, represented in this article by Singapore and Thailand, is a key region to test whether the post-Lisbon EU has reached the status of a key actor on the global stage. The findings from media research carried out in 2006 and 2011 (i. e. before and after the Lisbon Treaty) suggest that the EU has failed to achieve its stated aims.
\end{abstract}

Keywords: EU, media, perceptions, Singapore, Thailand

\section{Introduction: EU external action after the Lisbon Treaty}

The appointment of Baroness Catherine Ashton in November 2009 as the European Union's (EU) High Representative of the Union for Foreign Affairs and Security Policy (HR FASP) was heralded by European Commission President José Manuel Barroso to be the answer to the question by former US 
Secretary of State Henry Kissinger: "Who do I call if I want to speak to Europe?" (Brunnstrom, 2009). The Lisbon Treaty's creation of the High Representative's role, together with the newly formed European External Action Service (EEAS) as well as the role of the President of the European Council, were intended to "effectively project European values and interests worldwide" (Šefčovič, n.d.) and to make Europe "an actor on the global stage" (Europa, n.d.).

This paper seeks to determine whether the EU has achieved its objectives concerning the visibility of EU's external action, which the provisions of the Lisbon Treaty sought to address. Herman Van Rompuy, President of the European Council, and the two posts held by Catherine Ashton, along with the Presidency of the European Commission, held currently by José Manuel Barroso, represent the EU's 'main three faces to the world' all with a role in the EU's external affairs (Hughes, 2008). In the post-Lisbon era, the EU was to be perceived as a consistent actor on the world stage, and personified by the likes of Catherine Ashton and Herman Van Rompuy. This coherent picture is in contrast to the pre-Lisbon era characterised by rotating EU presidencies held by the Member States vis-à-vis the various EU institutions.

However, drawing on a series of studies, which began with Hill's identification of the 'capability-expectations gap' that has afflicted the EU for the last two decades (Hill, 1993, pp. 305-328), the research which underpins the findings in this paper hypothesised an EU external communication deficit. The data employed in this paper comes from two phases of research projects conducted by the National Centre for Research on Europe, University of Canterbury (New Zealand), which studied the media imagery of the EU in the national news discourse of countries in the Asia-Pacific. The first year-long study was conducted in 2006; the second took place in the first half of 2011. Both phases of the project adhered to the same methodology, and thus can provide a valid assessment of the external media perceptions of the EU before and after the Lisbon Treaty came into force on 1 December 2009. Singapore and Thailand were selected for analysis as they were the two Southeast Asian cases in the research project with a comparable pre- and post-Lisbon time frame.

Southeast Asia is a key region to test whether a post-Lisbon EU has reached a status of a pronounced and recognised actor on the global stage is. Southeast Asia is the location where region-building has gone the furthest in the form of the Association of Southeast Asian Nations (ASEAN) founded in 1967. In this region, European integration has been closely studied and even admired occasionally, particularly within civil society. The EU-the first dialogue partner for ASEAN — has in recent years also been involved with supporting 
the further integration of ASEAN through its ASEAN-EU Regional Integration Support (APRIS) programme. In terms of drafting of the ASEAN Charter (often compared with the Constitutional Treaty of the EU) and the aspiration of achieving an ASEAN Community by 2015, many comparisons have been made between the two regions, and one would therefore assume that the EU would be fairly visible in this region.

\section{Setting the context-the longstanding EU-ASEAN partnership with some caveats?}

The EU and ASEAN have had a longstanding partnership dating back to the early 1970s which was formalised in 1980 with the signing of the Cooperation Agreement during the $2^{\text {nd }}$ ASEAN-EC Ministerial Meeting. Yet, despite this there remains a widespread perception that the EU underestimates the importance of ASEAN in Asia. ASEAN has always been of low priority for the EU, and though trade and investment between the two regions have grown over the years, the quality of the relationship has been less than optimal. EU-ASEAN relations have suffered from two factors: the EU's obsession with the rise of China and sanctions on Myanmar (Burma). Despite the rhetoric of the 1990s about developing an equal partnership between ASEAN and EU, and the stated vision in the 1994 EU policy paper Towards a New Asia Strategy, placing EUASEAN relations as the cornerstone of the EU's engagement with broader Asia (European Commission, 1994) ASEAN has felt neglected by the EU.

Ashton made her first visit to Southeast Asia as HR FASP (and Vice-President of the European Commission) only as late as April 2012 - during the third year of her appointment - when she travelled to Brunei Darussalam for the $19^{\text {th }}$ ASEAN-EU Ministerial Meeting (AEMM) and then on to Myanmar/Burma to open the first EU office there. This is a stark contrast to Javier Solana, the former EU High Representative for Common Foreign and Security Policy, who regularly attended the ASEAN Regional Forum (ARF), and also to other officials such as former US Secretary of State Hillary Clinton. It is difficult to avoid the conclusion that such neglect reflects the EU's lack of strategic understanding of the region and a failure to perceive the centrality of ASEAN in the emerging regional architecture of the broader Asia-Pacific.

European powers like the British, French and the Dutch were present in Southeast Asia from the nineteenth century into the mid-twentieth century through their colonies of Singapore, Malaya, French Indochina and the Dutch East Indies. In 
addition to the cultural and institutional influences that endure from the colonial period, trade with these European countries has also generally continued, often at relatively high levels. The EU remains predominantly an economic player in Asia and constitutes ASEAN's second largest trading partner overall. Singapore, for instance, is the EU's twelfth largest trading partner, and ranks fifth in Asia (EU Delegation to Singapore, 2011). However, a breakdown of export figures reveals that in 2011, altogether 45.1 per cent of total exports from the EU to Singapore came from the three EU Member States who had regional colonial ties - the United Kingdom, France, and the Netherlands - with a further 23.5 per cent coming from Germany alone. ${ }^{1}$ Perhaps because of the colonial history of a handful of former European colonial powers, bilateral ties still trump EUSingapore ties.

\section{The EU as an international actor}

Despite the sui generis nature of the internal functioning of the EU, there is a consensus that it can be studied as an international actor like any other state actor. In mainstream international relations theory, the concept of actorness is biased towards a state-centric perspective, disadvantaging a balanced understanding of the EU's role in the international system. Nonetheless, there is a general agreement that the EU is an important actor on the world stage; opinion diverges, however, on the quality of the EU's actorness and its identity, both internal and external. Consequently, scholars have differentiated the EU as an international power from others powers in the more traditional mould, such as the United States or China. The international role of the EU has thus been variously conceptualised as a "superpower in the making" (Galtung, 1973), an "international presence" and an "international identity" (Allen \& Smith, 1990, pp. 19-38), "normative power" (Manners, 2002, pp. 235-258), a "civilian power" (Whitman, 1998, pp. 149-164), "soft power" (Nye, 2004), "peace power" (Ehrhart, 2005, pp. 87-99), "ethical power" (Aggestam, 2008, pp. 1-11), and by politicians as a "model power" (Miliband, 2007) or "smart power" (Ferrero-Waldner, 2008). The academic discussions and debates of the EU's international role naturally intensified when the Common Foreign and Security Policy was introduced in the Treaty of Maastricht, formally expressing the EU's ambitions on world stage.

Sjöstedt (1977), writing in the pre-Maastricht era, offered a definition of European Community actorness as "the capacity to behave actively and deliberately in

Figures computed from Eurostat (Comext, Statistical regime 4). 
relation to other actors in the international system". This is predicated on the notion of actorness as political cohesion, defined as "the Union's capacity to aggregate preferences and select policies on international issues, and then to pursue them in relations with other states, non-state actors and international institutions" (Thomas, 2010, p. 5). For Hill (1993), the actorness of the EU touches on its distinctiveness from other political entities, and the autonomy it enjoys in making its own laws; nonetheless he acknowledges that the EU possesses a variety of actor capabilities. This paper argues that the EU can therefore be studied as an actor in the international system in the same way as the United States and China, no matter how unique its internal characteristics may be.

Actorness of the EU can also be understood as the result of a dynamic process between the aforementioned actorness, presence and of regionness, as defined by Hettne (2007, p. 111) in terms of internal integration and identity formation, and as an indication of the relative cohesion of a given region. Seen this way, actorness is the "outcome of a dialectic process between endogenous and exogenous forces" (Hettne, 2007). Related to this is Allen and Smith's (1998) concept of presence defined as the legitimacy and capacity to act and to mobilise resources, and the perception an actor generates about itself. They have written of the EU's presence in the international arena in terms of both its external behaviour, and the way it is perceived by other international actors.

It was Hill who in 1993 famously identified the capability-expectations gap, in reference to the gulf which emerged between what the EU increasingly was expected to do and the means and capacities it actually possessed, concluding that the EU was not an effective international actor. In hypothesising the EU's external communication deficit, Chaban and Holland (2010) have examined the EU's external imagery in the media and public discourses across six Asian localities and found that the EU is not seen as a social and environmental actor, although the EU's official rhetoric highlights itself as a "world champion" of those very issues. Not only did the expectation that the EU's global influence on social and environmental issues would translate into popular topics in the external media prove unfounded, the public opinion also confirmed that the most common images people held of the EU excluded these social and environmental aspects.

Perceptions matter because "they are a basis for understanding and a foundation upon which to make choices and decisions" (IDEA, 2009, p. 16). Studying external perceptions also aids in evaluating whether gaps exist between the expectations and the capabilities (or realities) of the EU (Hill, 1998, p. 6). Although perceptions may be inherently irrational or mysterious, given the 
proclivity of human nature towards error and lack of objectivity, perceptions have had a very real propensity for fuelling xenophobic attitudes on a national scale (Chaban \& Holland, 2010, p. 127).

There is a growing body of literature on the EU's external imagery (Chaban \& Holland, 2010; Lucarelli \& Fioramonti, 2010), including studies on how the eurozone debt crisis has affected external perceptions of the EU within Asia (Lisbonne-de Vergeron, 2012). However, longitudinal analyses of EU's external imagery in the media before and after the implementation of the Lisbon Treaty and, especially, studies of perceptions from Southeast Asia, have not previously been conducted.

\section{The EU's external action and the High Representative for Foreign Affairs and Security Policy}

Scholars like Nuttall (2005) have noted that as the scope of tasks for the EU globally continues to grow, the perceived problem of lack of coherence and efficiency in the EU's external actions increases correspondingly. Yet others like Thomas (2010, p. 11) believe it is "misinformed or misleading" that officials tend to link the EU's frequent lack of coherence to its frequent ineffectiveness on foreign and security policy because the former is necessary but not sufficient to achieve the latter. Nonetheless, for a foreign policy actor there is a relationship between coherence and effectiveness.

The office of the HR FASP was the latest initiative in a range of institutional changes to enhance the efficiency of cooperation between the Member States and to "ensure the consistency of the Union's external action" (Art. 18 (4) TEU) in giving it a 'single voice' and 'face'. To fulfil these tasks, the office of the High Representative combined the previous two posts of the High Representative of the CFSP, held by Javier Solana, and that of the European Commissioner for External Relations, last held by Benita Ferrero-Waldner. Furthermore, the High Representative was to chair the Foreign Affairs Council. The official rhetoric is also unequivocal on the aims of the Lisbon Treaty for external action. According to Maroš Šefčovič, Vice-President of the European Commission:

Another major innovation of the Lisbon Treaty is the setting up of the European External Action Service (EEAS) to bring greater coherence to the Union's external or foreign policy. The EEAS will help the High Representative for foreign affairs and security policy fulfil her 
mandate to develop and coordinate EU foreign policy and coherently and effectively project European values and interests worldwide. The EEAS will be composed of officials from the Commission, the Secretariat of the Council and the diplomatic services of EU Member Countries, as well as local and contract staff. (Šefčovič, n.d., emphasis added)

Article 9E of the article of the Lisbon Treaty describes the role of the High Representative as follows:

The High Representative shall be one of the Vice-Presidents of the Commission. He (sic) shall ensure the consistency of the Union's external action. He shall be responsible within the Commission for responsibilities incumbent on it in external relations and for coordinating other aspects of the Union's external action. (Lisbon Treaty, 2007)

Polls suggest that EU citizens themselves support a stronger, single EU global role - one such poll, conducted by the German Marshall Fund of the US in 2007, identified almost 90 per cent of respondents calling for the EU to take on greater responsibility on the world stage (Holland et al., 2007). Eurobarometer results further affirm that over the last decade EU citizens value the EU's global role on key international issues.

Wessels and Bopp (2008, p. 30) may have provided the prophetic warning that "the efficiency and general performance of the Union's crisis management operations will have to be tested in actual moments of crisis, providing the 'right' kind of challenges to the Union's action capability", and that "the capability of the Union to act as a global actor in the international system remain(s) open". They also predicted that in order to be able to establish general acceptance and consensus in spite of this institutional and procedural pressure, the High Representative would probably have to pursue a "low profile" policy especially in times of crisis or conflict, when the involved actors and institutions have diverging interests (Wessels \& Bopp, 2008, p. 22). The same scholars have judged that the "fulfilment of his/her tasks within the institutional architecture will very much depend on his/ her capability to move and act within and in between the different 'hats"' (Wessels $\&$ Bopp, 2008, p. 22). Warnings that the broader aspects of the EU's interests and goals in its external activities would be lost with potential turf-fights between the European Commission and Council secretariats, and between them and the Member States, were articulated by Hughes (2008). Additionally, the UK's House of Commons Foreign Affairs Committee warned that the potential of the HR to 
perform "could be jeopardised by a plethora of duties and excessive workload" (House of Commons, 2008, p. 5).

\section{Methodology}

Why should an analysis of the media be considered the appropriate avenue to assess the achievements of the Lisbon Treaty and the EEAS? For Galtung and Ruge (1965, p. 64), the "regularity, ubiquity and perseverance of news media will [...] make them first-rate competitors for the number-one position as international image-former". In complex issues such as foreign affairs, ordinary people are largely "passive targets of political text and talk" (Van Dijk, 1998).

The monitored media outlets were those with the highest national circulation and viewership numbers covering four categories - one business paper, one popular paper, one English language paper, and one television news channel. In Singapore, these were The Business Times, Lianhe Zaobao, The Straits Times and the Channel 8 evening new channel. ${ }^{2}$ In Thailand, these were The Manager, Thai Rath, Bangkok Post and the Thai PBS (formerly known as TITV) evening news channel, respectively. ${ }^{3}$

For a newspaper article or television news segment to qualify as an 'EU news' item, the article had to contain a mention of at least one of the following terms: European Union/EU; eurozone; euro; European Commission/EC; European Parliament/EP; European Central Bank /ECB; European Court of Justice/ECJ; Asia-Europe Meeting/ASEM.

The names of individual EU Member States or Member State officials were not search terms. However, the mention of these names within the pool of identified

2 The Business Times is an English-language business newspaper with a daily circulation of 30,000. Lianhe Zaobao is a Chinese-language newspaper with a daily circulation of 200,000. The Straits Times is the major English-language newspaper in Singapore with a daily circulation of 400,000. All newspapers in Singapore are owned by the Singapore Press Holdings, over which the government exercises indirect control. Channel 8, a Mandarin Chinese television channel with a 34 per cent market share (2004 figure), is operated by MediaCorp, which is owned by the sovereign wealth fund Temasek Holdings.

3 The Manager (Phujatkan in Thai) is a business newspaper with a daily circulation of 100,000. Thai Rath, a tabloid-style paper, is the biggest selling newspaper in Thailand with a daily circulation of 1 million. Bangkok Post is one of the two English-language newspapers in Thailand, with a daily circulation of 80,000 . These newspapers are privately owned. Thai Public Service Broadcasting (Thai PBS) was known before 2008 as TITV and even earlier as ITV. These media outlets, except Bangkok Post, use the Thai language. 
EU news items was noted for additional analysis. This study therefore considers the mention of individual Member States only in the context of so-defined 'EU news'.

To determine whether or not the EU was depicted as an economic, political, social, environmental or developmental actor in the news, the notion of frames is used. The study followed Entman's (1993, p. 52) definition of 'framing' as the "selection of some aspects of perceived reality to make them more salient in a communication text, in such a way as to promote a particular problem definition, causal interpretation, moral evaluation and/or treatment recommendations". Such a conceptualisation of framing has been regularly and effectively applied to studies of the EU's representations in media discourses (Holland et al., 2007; De Vreese, 2002; Peter et al., 2003).

Additionally, the use of conceptual metaphors in the language used to characterise EU actors was recorded. Just as EU and EU-related institutions were at times characterised by human-related metaphors, EU and EU-related officials were on occasion characterised by non-human metaphors. In both cases the effect was noted to further evaluate how they were portrayed. A new dimension was added to the 2011 phase of the project - the recording of visual imagery used in news items. Information on the contents and the manner in which EU-related figures or physical structures were portrayed in photographs accompanying the EU news items were recorded. Similarly, cartoons and graphs were also recorded. This aimed to further refine both the scale and quality of visibility that EU actors were accorded in the media.

The year 2006 was a "routine" one for the EU internally, in that there were no major EU initiatives, reforms or political events such as European Parliament elections (Holland et al., 2007, p. 31). In contrast, news of the eurozone sovereign debt crisis, in particular in Greece and Portugal, dominated global media coverage in 2011. Nevertheless, as noted below, with regard to the Singapore media findings, this did not have the effect of inflating the number of EU news items published vis-à-vis the 2006 findings. Petchsiri, Kirtiputra and Raveepaopong (2007, p. 198) observed that Thailand's coup d'état in September 2006 and the subsequent period of political instability resulted in a "media inclination to look inward" and "diverted much attention away from external actors such as the EU". In 2011, the political situation in Thailand had significantly stabilised.

There were general elections in Singapore in both 2006 and 2011, during the periods monitored by the project. However, the election campaigns lasted for 
only around ten days each, as is typically the case in Singapore. The early part of 2011 saw some key negotiation rounds in the Singapore-EU Free Trade agreement (FTA). However, again, this did not have the effect of increasing the media's coverage of the EU. In fact, only a handful of news items on the FTA were published. In comparison, the EU-Korea FTA garnered far greater coverage and discourse in the South Korean media, during the corresponding period. $^{4}$

Clearly, the different domestic political environments in individual Southeast Asian countries may account for the nuanced differences in perceptions of the EU found in Singapore and Thailand. Thailand, which began its democratic transition much earlier and has a more active civil society, may tend to have a more positive view of the EU as a normative power, and look towards the EU for support on human rights issues, for example. Thailand's freer press contrasts with Singapore's media which is controlled by the government through the Newspapers and Printing Press Act of 1974. Civil society-state relations in Singapore have been characterised as one of "tension and constant negotiation" (Koh \& Soon, 2011).

\section{Findings}

\subsection{Most visible officials (EU and EU Member States)}

In 2006, Javier Solana was clearly the most visible EU or EU Member State official in both the Singaporean and Thai media, with appearances in 4.4 and 5.7 per cent of all news items for that year respectively (Fig. 1). This was the case even though a narrow majority of the news items focused on the economy rather than politics or diplomacy that were Solana's mandated competences. The picture was different in 2011 - in the Singapore media, Jean-Claude Trichet was by the far the most visible EU or EU Member State official appearing in 9.3 per cent of EU news items; in the Thai media, Catherine Ashton and Angela Merkel shared that honour, each with appearances in 2.1 per cent of EU news items (Fig. 2). All this was set against a significantly higher percentage of 2011 EU news items on the economy than in 2006, due to the worldwide dominance of reportage on the eurozone sovereign debt crisis.

The sample sizes are given as $n$ values in the following figures. Note that the media was monitored for an entire year in 2006, but only for six months (from January to June) in 2011.

$4 \quad$ See Sung-Won Yoon's paper in this journal issue (pp. 37-58). 
Figure 1. Visibility of EU and EU MS officials in Singapore ${ }^{5}$

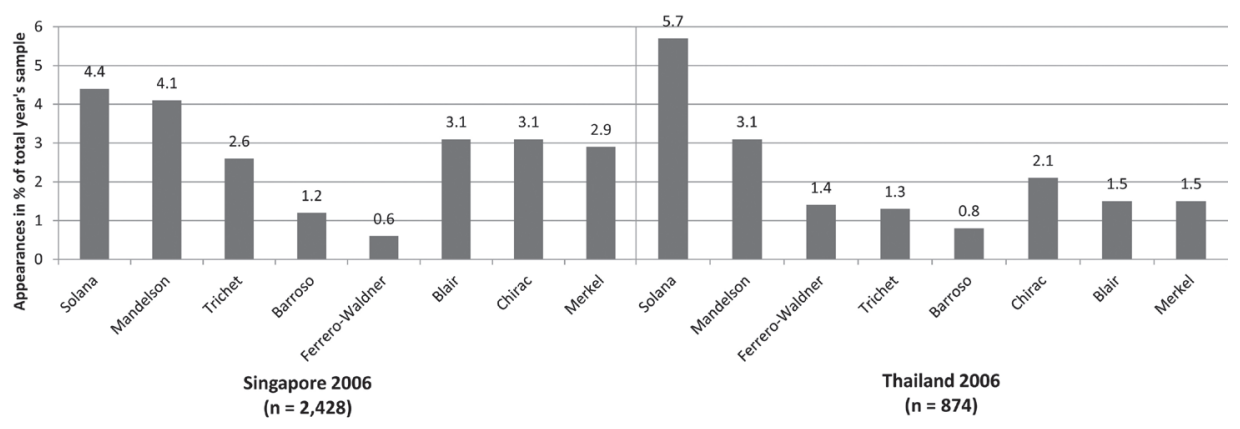

Figure 2. Visibility of EU and EU MS officials in Thailand

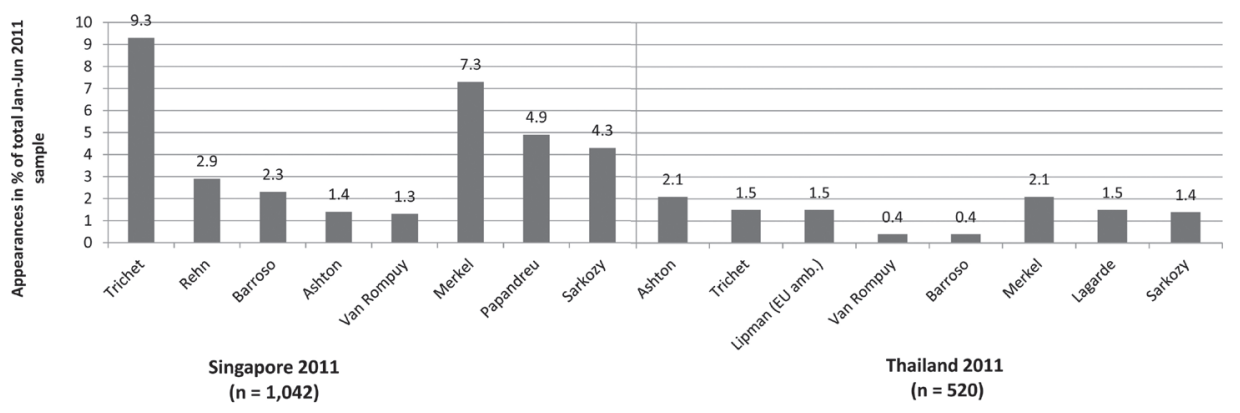

Full names of officials and their positions during the year in question (for Figs. 1 and 2):

Solana = Javier Solana, EU High Representative for Common Foreign and Security Policy

Mandelson $=$ Peter Mandelson, European Commissioner for Trade

Trichet $=$ Jean-Claude Trichet, President of the European Central Bank

Barroso $=$ José Manuel Barroso, President of the European Commission

Ferrero-Waldner $=$ Benita Ferrero-Waldner, European Commissioner for External Relations and European Neighbourhood Policy

Blair $=$ Tony Blair, British Prime Minister

Chirac $=$ Jacques Chirac, French President

Merkel $=$ Angela Merkel, German Chancellor

Rehn $=$ Olli Rehn, European Commissioner for Economic and Monetary Affairs and the Euro and Vice-President of the European Commission

Ashton $=$ Catherine Ashton, Baroness Ashton of Upholland, EU High Representative of the Union for Foreign Affairs and Security Policy

Van Rompuy = Herman Van Rompuy, President of the European Council

Papandreou $=$ George Papandreou, Greek Prime Minister

Sarkozy $=$ Nicholas Sarkozy, French President

Lipman $(E U$ amb. $)=$ David Lipman, Ambassador and Head of Delegation of the EU to Thailand, Cambodia, Laos and Myanmar

Lagarde $=$ Christine Lagarde, French Minister of Finance, later Managing Director of the International Monetary Fund 
The dominance of Jean-Claude Trichet in the Singapore media in 2011 was not limited to his frequent public appearances. The media coverage of him was indepth and flattering. To draw on the conceptual metaphors used in the news items to characterise him, Trichet was frequently portrayed as a figure of authoritysomeone firmly "at the helm of the ECB" who would "combat the [eurozone] crisis" (e.g., The Business Times, 2011a,b,c). The visual imagery of him was also consistent with these characteristics. Not only was he frequently featured in photographs accompanying news items on the EU-a rare occurrence for an EU official in all of the cases monitored in this paper-he was consistently portrayed as a commandeering person.

Javier Solana in 2006 was not accorded such deep or flattering coverage, despite his being the most visible EU or EU Member State official in terms of the sheer number of appearances. Importantly, conceptual metaphors were rarely used to describe him, suggesting that while he was mentioned frequently, it was only in passing. ${ }^{6}$ The visual imagery of EU actors was not recorded in the 2006 phase of the project.

\subsection{Most visible EU institution/Member State}

The European Commission was the most visible EU institution in both the Singaporean and Thai media in 2006 (Fig. 3): in 2011 the European Central Bank took its place (Fig. 4). Nevertheless, individual EU Member States were the most visible EU institution still far more visible than EU institutions in both Singapore and Thailand in 2006 and 2011.

The visibility of the rotating presidency of the EU over time is perhaps of interest, given that the Lisbon Treaty aimed to reduce its role while promoting that of the President of the European Council. In the Singapore media, the rotating presidency - held by Austria and then Finland in 2006, and by Hungary in the first half of 2011 - never attracted more than a few mentions in either years. In the Thai media there was no mention of the rotating presidency at all in either year.

6 'EU foreign policy chief Javier Solana voiced surprise and impatience' was just about the only conceptual metaphor used on Solana, see The Straits Times, 2006. 
Figure 3. The most visible EU institutions (2006) ${ }^{7}$

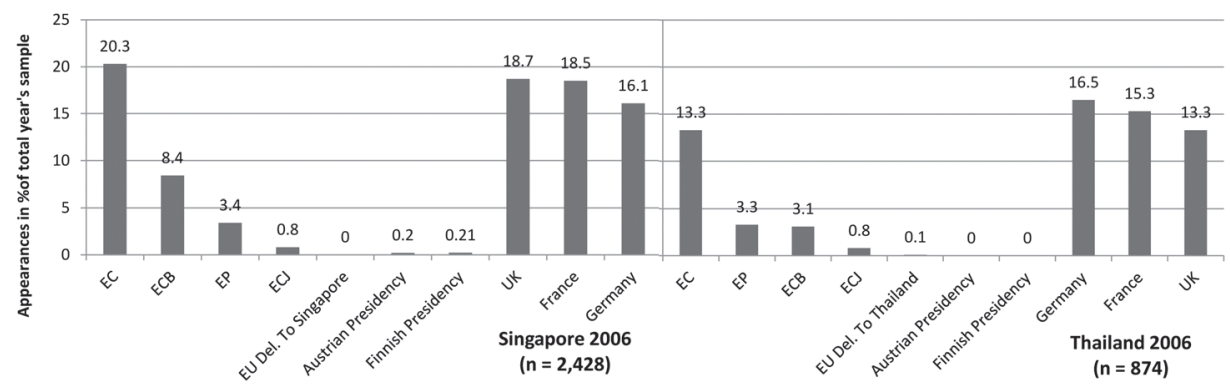

Figure 4. The most visible EU institutions (2011)

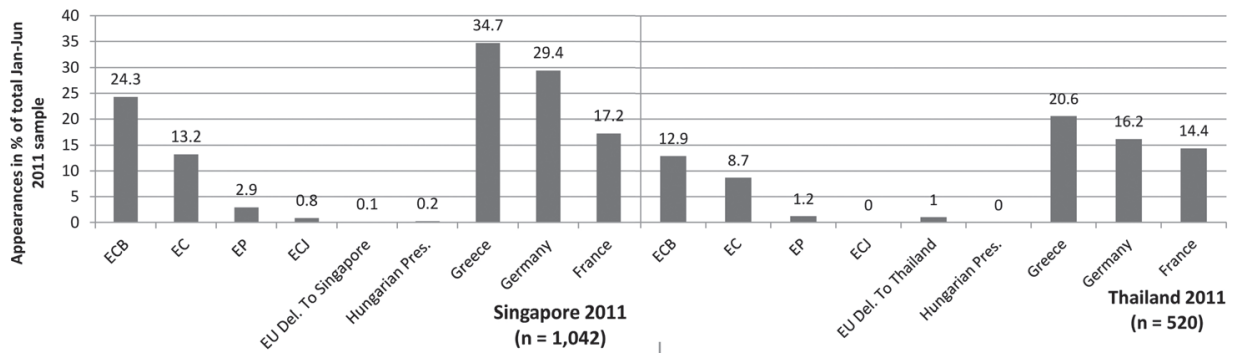

\subsection{News framings}

The predominant news framings have already been alluded to above. In 2011, news on the economy accounted for 69 per cent of all items in the Thai media and 73 per cent in the Singapore media; the other themes were of political connotation (correspondingly, 39 per cent and 36 per cent), social affairs (17 per cent and 15 per cent), environment ( 2 per cent and 3 per cent), and development ( 1 per cent for both Thailand and Singapore). Even in 2006 before the eurozone sovereign debt crisis, news items on the economy made up 41 per cent of all media items in Thailand and 45 per cent in Singapore; politics was on the second place with correspondingly 16 per cent and 17 per cent, followed by social affairs-related news ( 12 per cent and 7 per cent), news on environment ( 2 per cent and 3 per cent), and development (1 per cent in Thailand and absolutely none in Singapore).

Full names of institutions (for Figs. 3 and 4):

$\mathrm{ECB}=$ European Central Bank

$\mathrm{EC}=$ European Commission

$\mathrm{EP}=$ European Parliament

$\mathrm{ECJ}=$ European Court of Justice

EU Del. to Singapore/Thailand = Delegation of the EU to Singapore/Thailand

Austrian Presidency = Austria's Presidency of the EU (first half of 2006)

Finnish Presidency = Finland's Presidency of the EU (second half of 2006)

Hungarian Pres. $=$ Hungary's Presidency of the EU (first half of 2011) 
By way of comparison, the media in China has consistently presented the EU more strongly as a political actor in the media than any other Asian country. ${ }^{8}$

It is tempting to write off these findings as being skewed by the media's coverage of the eurozone debt crises in 2011, as this was an extraordinary event. The crisis, however, has certainly not had the effect of increasing the sheer number of overall EU news items in the Singapore media — in fact, the monthly average number of EU news items in the media outlets monitored in 2011 was 173.7 items compared with 202.3 items during the 'routine year' of 2006. In the Thai media, the monthly average number of EU news items in 2011 was 86.7 items, albeit marginally higher than the 72.8 items in 2006.

\section{Analysis}

Despite all the aspirations expressed in the Lisbon Treaty to make the EU more coherent and visible, the EU continued to be perceived as hesitant, reactive and uncertain of its role on the world stage. It is perhaps unfortunate that the global financial crisis and sovereign debt crisis occurred at the time when the Lisbon Treaty came into force. Yet, it may underline the fact that in spite of the legalistic and formal treaty changes, without accompanying political imagination and political will, and a truly European strategic vision of the world beyond the EU's borders, the EU will never be viewed as a serious global player. Indeed, the very idea of an EU foreign policy could be questioned.

The findings of this project reveal the intricacies of how the external perceptions of the EU developed both before and after the Lisbon Treaty came into force. Even with the enlarged mandate conferred on her new role by the Lisbon Treaty and the EEAS to support her, Catherine Ashton was only marginally visible in the Singaporean media in 2011, featuring in just 1.4 per cent of all EU news items. None of these news items included an accompanying photograph of Ashton, nor was she mentioned more than just in passing. An exception, however, was an article written by her on the occasion of Europe Day on 9 May which was carried in The Straits Times, a somewhat novel and direct way to overcome media disinterest! A similar lack of attention was also given to Herman Van Rompuy as President of the European Council. In the Thai media, Ashton was tied with Angela Merkel in the sheer number of appearances (both were mentioned in just 2.1 per cent of all EU new items), leading to the reasonable conclusion that the EU is quite literally largely presented as a faceless entity in Thailand.

8 See Suet-Yi Lai's and Li Zhang's paper in this volume (pp. 13-36). 
However, it cannot be alleged that the EU is incapable of presenting a clear and visible figure who can articulate a coherent and common foreign policy: in 2006, the previous High Representative for CSFP Javier Solana, achieved the most mentions of any EU or EU Member State official in both the Singaporean and Thai media. Indeed, in the pre-Lisbon Treaty era, the High Representative for CSFP had "considerably raised the EU's external profile the 'single face' of Javier Solana [had] almost become emblematic of EU foreign policy" (Holland et al., 2007, p. 228).

Is this comparative invisibility because Ashton's office was simply not equipped to deal with economic and financial crises, which dominated the media's coverage of the EU in 2011? The high visibility of Jean-Claude Trichet in the Singaporean media, with in-depth coverage in 9.3 per cent of all EU news items, confirms that the EU official mandated to oversee the single currency had been given due media exposure. Similarly Olli Rehn, the European Commissioner for Economic and Financial Affairs, and Jean-Claude Juncker, in his capacity as President of the Eurogroup attracted more mentions than Ashton. The high visibility of Greece as an EU Member State and the Greek Prime Ministernever mentioned in the media in 2006-further confirms the preponderance of stories on the sovereign debt crisis.

Solana's role was also not equipped to deal with this. In the 2006 data, the EU was also presented primarily as an economic actor overshadowing its political or social roles, albeit with a slimmer majority of the news items - with around 40 per cent of all EU items on the economy. Yet, when it came to EU news, Solana was more visible than any other EU official or EU Member State official in both the Thai and Singaporean media. Considering that this was achieved with a more modest mandate than Ashton currently has under the Lisbon Treaty, one could infer that the personality and personal strategy of an 'EU foreign minister' has a greater bearing on the publicity of the office and of the EU as a whole.

But there is also a more obvious point regarding the travelling schedules of the two High Representatives. Whereas Solana made it a point to attend the ASEAN Regional Forum (ARF) and made a number of visits to Southeast Asian countries, as already noted above, Ashton only made her first visit to the region some two and a half years after her appointment, in April 2012. Nonetheless, subsequent visits culminated in her signing the Instrument of Accession of the EU to the Treaty of Amity and Cooperation, at the ARF in Cambodia in July 2012. Given that Ashton had not made any visits to Southeast Asia until after the period of the media analysis in this analysis (January-June 2011), it is little wonder that the media in that part of the world was so unenthusiastic about her. 
The role of the President of the European Council was intended to gradually displace that of the rotating presidency. Going by that benchmark, Van Rompuy has been reasonably successful in his mandate, with appearances in 1.3 per cent of news items in the Singapore media in 2011. Like the Singapore media coverage of Catherine Ashton, Van Rompuy was only mentioned in passing and never featured in any photographs accompanying the news articles. But the rotating EU presidencies were never very visible in the media to begin with. Coverage in Singapore remained unchanged with only a few mentions after the Lisbon Treaty came into force. In Thailand, the rotating EU presidencies were not referenced in any media story in 2006. It must surely have helped somewhat to have attached a face - and a permanent one at that — to the presidency of the European Council.

In comparison to Ashton and Van Rompuy, the European Commissionfrequently presented as the 'executive arm' of the EU in the media- and its President Barroso still appear as the main actor for the "EU's position", notwithstanding the dominance of the European Central Bank and Trichet in 2011. It remains to be determined whether journalists are simply more familiar with the European Commission - an institution that has been known as such since the late $1950 \mathrm{~s}$ - and need time to fully appreciate and understand the new offices held by Ashton and Van Rompuy.

It is unlikely that anyone would dispute that Barack Obama and Hu Jintao personify their respective countries in a way that no one individual can represent the EU. It would therefore be of interest in future studies to conduct the same analysis of external media perceptions of the EU in a comparative study where actors of other major world powers like the United States and China are also examined.

\section{Conclusion}

The media findings cited in this paper suggest that by second year of operation the office of the HR FASP had largely not achieved its objectives with regard to the EU's external action in Southeast Asia - namely, that the High Representative had not "coherently and effectively project[ed] European values and interests worldwide" (Šefčovič, n.d.). In the first half of 2011 in the Singapore and Thai media Jean-Claude Trichet, as President of the European Central Bank, and the leaders of individual EU Member States, most conspicuously German Chancellor Angela Merkel, were seen to be acting for the EU far more than 
Catherine Ashton. The theoretical literature makes a convincing case for the EU to be studied as an international actor alongside other powers like the United States; by the same token, the coherence and effectiveness of the EU's actorness has been found to be wanting.

The effectiveness of the EU's external action could perhaps be measured beyond just the number and quality of appearances of EU officials and institutions in the media. But with a plethora of actors, whether individual or institutional, all somehow representing the 'face of the EU' in the media, this lack of coherence is not perceived as positive in the minds of ordinary people who are getting passively targeted by political word in print as well as speaking (Van Dijk, 1998). The provisions of the Lisbon Treaty sought to address precisely this, but two years on from its implementation, the effects in Southeast Asia appear modest at best.

In conclusion, it needs to be addressed whether the eurozone sovereign debt crisis has qualitatively skewed the media coverage of the EU. The question posed is whether the dominance of the crisis in the media has had the effect of marginalising the standing of High Representative Catherine Ashton, whose mandate does not extend to the economic and financial aspects of the Union. Any doubts should be put to rest with the placing of Ashton as the most visible EU official in the media of China during the same period. Is this relative lack of coverage in Singapore and Thailand a reflection of the fact that the High Representative has thus far shown minimal interest in Southeast Asia as evidenced by her rare visits to the region? Wessels and Bopp (2008, p. 22) may therefore have rightly predicted that the realisation of goals within the framework of institutional architecture will depend on the High Representative's aptitude to operate "within and in between the different "hats"".

Dr. Yeo Lay Hwee is Director of the European Union Centre in Singapore since 2009. She is also Council Secretary and Senior Research Fellow at the Singapore Institute of International Affairs (SIIA), and Adjunct Research Fellow at the S. Rajaratnam School of International Studies (RSIS), and teaches part time at the National University of Singapore. Lay Hwee sits on the Advisory Board of the Centre for European Studies at the Australian National University (ANUCES) and also the Advisory Board of KU Leuven's Master in European Studies (MAES) Programme. She is active in various Asia-Europe networks such as the Agora EU-Asia Network. Since June 2011, she has been appointed the co-Editor-inChief of the Asia Europe Journal published by Springer. An international relations expert, her research interests revolve around comparative regionalism; Asia-Europe relations in general, and in particular, relations between the European Union and ASEAN (Association of Southeast Asian Nations); and the Asia-Europe Meeting (ASEM) process. 
Loke Hoe Yeong is Associate at the EU Centre in Singapore, and Researcher at the Singapore Institute of International Affairs. He was the Singapore researcher for the 'After Lisbon: The EU as an Exporter of Values and Norms through ASEM' project led by the National Centre for Research on Europe, New Zealand. He holds an MSc in Comparative Politics from the London School of Economics and Political Science, and a BSc in Politics \& International Relations from the University of London. His research interests include regional integration (EU, ASEAN and Asia) and conflict studies.

\section{References}

Aggestam, L. (2008), 'Introduction: ethical power Europe?' International Affairs, vol. 84, no. 1, pp. 1-11. http://dx.doi.org/10.1111/j.1468-2346.2008.00685.x

Allen, D. \& Smith, M. (1990), 'Western Europe's Presence in the Contemporary International Arena,' Review of International Studies, vol. 16, no. 1, pp. 19-37. http://dx.doi.org/10.1017/S0260210500112628

(1998), “The European Union's Security Presence: Barrier, Facilitator or Manager?" in C. Rhodes (ed.) The European Union in the World Community, Boulder: Lynne Reiner, pp. 45-63.

Brunnstrom, D. (2009), 'EU says it has solved the Kissinger question,' Reuters, 20 November 2009. Retrieved from http:/www.reuters.com/article/2009/11/20/useu-president-kissinger-idUSTRE5AJ00B20091120 [accessed 1 Aug 2012]

Chaban, N. \& Holland, M. (2010), 'The EU in the eyes of Asia: Motivation and methodology,' Asia Europe Journal, vol. 8, no. 2, pp. 127-131. http://dx.doi. org/10.1007/s10308-010-0256-9

De Vreese, C. H. (2002), Framing Europe: Television News and European Integration, Amsterdam: Aksant Academic Publishers.

Ehrhart, H.-G. (2005), "Die EU und das Leitbild 'Friedensmacht': Außen- und sicherheitspolitische Konzepte nach dem Irak-Krieg," in T. Jäger, A. Höse \& K. Oppermann (eds.) Transatlantische Beziehungen: Sicherheit, Wirtschaft, Öffentlichkeit, Wiesbaden: VS Verlag für Sozialwissenschaften, pp. 87-99. http:// dx.doi.org/10.1007/978-3-322-80721-2_4

Entman, R. M. (1993), 'Framing: Toward Clarification of a Fractured Paradigm,' Journal of Communication, vol. 43, no. 4, pp. 51-58. http://dx.doi.org/10.1111/j.1460-2466.1993.tb01304.x

EU Delegation to Singapore (2011), 'EU-Singapore Trade and Investment 2011. Retrieved from http://eeas.europa.eu/delegations/singapore/documents/eu_ singapore/eu_booklet_2011_en.pdf [accessed 1 Aug 2012]

Europa (n.d.), 'The Treaty at a Glance,' Europa Website. Retrieved from http://europa. eu/lisbon_treaty/glance/index_en.htm [accessed 1 Aug 2012] 
European Commission (1994), Towards a New Asia Strategy, Communication from the Commission to the Council, COM (94) 314 final, 13 July 1994.

Ferrero-Waldner, B. (2008), 'Die EU-Außenpolitik nach Lissabon,' Speech presented on 25 January 2008, Vienna. Retrieved from http://ec.europa.eu/commission barroso/ferrero-waldner/index_de.htm [accessed 1 Aug 2012]

Galtung, J. (1973), The European Community: A Superpower in the Making, London: Allen and Unwin.

Galtung, J. \& Ruge, M. H. (1965), 'The Structure of Foreign News. The Presentation of the Congo, Cuba and Cyprus Crises in Four Norwegian Newspapers,' Journal of Peace Research, vol. 2, pp. 64-90. http://dx.doi.org/10.1177/002234336500200104

Hettne, B. (2007), 'Interregionalism and World Order: The Diverging EU and US Models,' in M. Telò (ed.) European Union and New Regionalism - Regional Actors and Global Governance in a Post-Hegemonic Era, Aldershot: Ashgate, pp. 107-126.

Hill, C. (1993), “The Capability Expectation Gap, or Conceptualizing Europe's International Role," JCMS: Journal of Common Market Studies, vol. 31, no. 3, pp. 305-328. http://dx.doi.org/10.1111/j.1468-5965.1993.tb00466.x

Holland, M.; Ryan, P.; Nowak, A. Z. \& Chaban, N., eds. (2007), The EU through the Eyes of Asia: Media, Public and Elite Perceptions in China, Japan, Korea, Singapore and Thailand, Warsaw \& Singapore: University of Warsaw.

House of Commons (2008), Foreign Policy Aspects of the Lisbon Treaty, House of Commons Foreign Affairs Committee, Third Report of Session 2007-08, London: The Stationery Office.

Hughes, K. (2008), Shaping Lisbon's Legacy: Who will make Foreign Policy? Paris: Friends of Europe.

IDEA (2009), Democracy in Development: Global Consultations on the EU's role in Democracy Building, Report of the International IDEA, Stockholm: International IDEA.

Koh, G. \& Soon, D. (2011), 'Singapore,' in T. Chong \& S. Elies (eds.) An ASEAN Community for All: Exploring the Scope for Civil Society Engagement, Singapore: Friedrich Ebert Stiftung \& Office for Regional Cooperation in Asia, pp. 111-126. Lisbon Treaty (2007), Full text of the Treaty, as published in Official Journal of the European Union. Retrieved from http://europa.eu/lisbon_treaty/glance/index_ en.htm [accessed 1 Aug 2012]

Lisbonne-de Vergeron, K. (2012), Chinese and Indian Views of Europe Since the Crisis: New perspectives from the emerging Asian giants, London \& Paris: KonradAdenauer-Stiftung, Global Policy Institute \& Robert Schumann Foundation.

Lucarelli, S. \& Fioramonti, L. (2010), External Perceptions of the European Union as a Global Actor, Abingdon \& New York: Routledge.

Manners, I. (2002), 'Normative Power Europe: A Contradiction in Terms?' JMCS: Journal of Common Market Studies, vol. 40, no. 2, pp. 235-258.

http://dx.doi.org/10.1111/1468-5965.00353 
Miliband, D. (2007), Speech by Rt Hon David Miliband presented at the College of Europe, Bruges, 15 November 2007. Retrieved from http://www.britischebotschaft. de/en/news/items/071115a.htm [accessed 1 Aug 2012]

Nuttall, S. (2005), 'Coherence and Consistency,' in C. Hill \& M. Smith (eds.) International Relations and the European Union, Oxford: Oxford University Press.

Nye, J. S. (2004), Soft Power: The Means to Success in World Politics, New York: Public Affairs.

Petchsiri, A.; Kirtiputra, T. \& Raveepaopong, R. (2007), 'Thailand: the EU Eclipsed?' in M. Holland et al. (eds.) The EU through the Eyes of Asia: Media, Public and Elite Perceptions in China, Japan, Korea, Singapore and Thailand, Warsaw \& Singapore: University of Warsaw, pp. 193-222.

Peter, J.; Semetko, H. A. \& De Vreese, C. H. (2003), 'EU Politics on Television News: A Cross-National Comparative Study,' European Union Politics, vol. 4, no. 3, pp. 305-327. http://dx.doi.org/10.1177/14651165030043003

Rhodes, C., ed. (1998), The European Union in the World Community, London: Lynne Rienner.

Sjöstedt, G. (1977), The External Role of the European Community, Farnborough: Saxon House.

Šefčovič, M. (n.d.), "Implementing the Lisbon Treaty," Inter-institutional relations and administration. Retrieved from http://ec.europa.eu/commission_2010-2014/ sefcovic/interinstitutional/lisbon/index_en.htm [accessed 1 Aug 2012]

Thomas, D. (2010), "Still Punching below its Weight? Actorness and Effectiveness in EU Foreign Policy," Paper presented at the UACES $40^{\text {th }}$ Anniversary conference, Bruges, 6-8 September 2010.

The Business Times (2011a), 'ECB rate hike likely in April, but not over 25bps,' The Business Times, 4 March 2011.

(2011b), "ECB's inflation stance gets market support," The Business Times, 16 March 2011.

(2011c), 'Berlin backs Italian in ECB chief bid: reports,' The Business Times, 25 April 2011.

The Straits Times (2006), 'Iran delays nuclear talks with EU', The Straits Times, 6 July 2006.

Van Dijk, T. (1998), Ideology: A Multidisciplinary Approach, London: Sage.

Wessels, W. \& Bopp, F. (2008), The Institutional Architecture of CFSP after the Lisbon Treaty: Constitutional breakthrough or challenges ahead? CEPS Challenge Paper No. 10, 23 June 2008.

Whitman, R. (1998), From Civilian Power to Superpower? The International Identity of the European Union, London: Macmillan.

http://dx.doi.org/10.1057/9780230375956 